$\sqrt{0}$

CHOICE

\title{
A systematic review of interventions to enhance medication adherence in children and adolescents with chronic illness
}

\author{
Angela J Dean, ${ }^{1-3}$ Julie Walters, ${ }^{4}$ Anthony Hall ${ }^{4,5}$
}

${ }^{1}$ Kids in Mind Research, Mater Child and Youth Mental Health Service, Mater Children's Hospital, South Brisbane, Australia

${ }^{2}$ The University of Queensland Queensland Brain Institute, St Lucia, Australia

${ }^{3}$ The University of Queensland School of Medicine, Herston,

Australia

${ }^{4}$ Mater Pharmacy Services,

South Brisbane, Australia

${ }^{5}$ Griffith University, School of

Pharmacy, Australia

\section{Correspondence to}

Dr Angela J Dean, Kids in Mind Research, Mater Child and

Youth Mental Health Service,

Mater Children's Hospital,

South Brisbane, Queensland

4101, Australia;

a.dean@uq.edu.au

Accepted 13 March 2010

\section{ABSTRACT \\ Introduction Poor medication adherence is common in children and adolescents with chronic illness, but there is uncertainty about the best way to enhance medication adherence in this group. The authors conducted a systematic review of controlled trials examining interventions that aim to improve medication adherence.}

Method A comprehensive literature search was undertaken to locate controlled trials that described specific interventions aiming to improve adherence to long-term medication, where participants were aged 18 years and under, medication adherence was reported as an outcome measure, and which could be implemented by individual health practitioners. Studies were reviewed for quality and outcome.

Results 17 studies met inclusion criteria: seven studies examined educational strategies, seven studies examined behavioural interventions and three studies examined educational intervention combined with other forms of psychological therapies. Only two of seven studies reported a clear benefit for education on medication adherence, whereas four of seven trials indicated a benefit of behavioural approaches on medication adherence. One trial reported that combining education with behavioural management may be more effective than education alone. Studies which combined education with other non-medication specific psychological interventions failed to demonstrate a beneficial effect on medication adherence. Only two studies examined adherencepromoting interventions in young people with established adherence problems.

Conclusion These findings suggest that education interventions alone are insufficient to promote adherence in children and adolescents, and that incorporating a behavioural component to adherence interventions may increase potential efficacy. Future research should examine interventions in high-risk groups.

\section{INTRODUCTION}

Adherence has been defined as 'the extent to which a person's behaviour corresponds with agreed recommendations from a healthcare provider'. ${ }^{1}$ Medication adherence refers to the degree to which the medications taken reflect the prescriber's intention. ${ }^{2}{ }^{3}$ Poor medication adherence is common, especially in chronic illness, ${ }^{134}$ and is associated with poorer outcomes. ${ }^{3} 56$ Interventions to promote adherence may be effective, although benefits are not consistently demonstrated across studies. ${ }^{4}$

\section{What is already known on this topic}

- Medication adherence is an important predictor of treatment outcomes.

- Poor medication adherence is common in children and adolescents with chronic illness.

\section{What this study adds}

- In children and adolescents, education interventions alone are insufficient to promote adherence; adding a behavioural component may enhance outcomes but a number of negative studies reinforce the need for more research.

- No studies have identified effective interventions for young people with established poor adherence.

Most existing reviews of adherence-promoting interventions have focused on adults. However, many young people experience chronic illness ${ }^{7} 8$ and poor medication adherence. ${ }^{9-12}$ Involvement of families in medication routines, ${ }^{12} 13$ and varying developmental capacities of children and adolescents ${ }^{11} 121415$ may influence medication adherence, reinforcing the need to identify interventions with demonstrated efficacy in young people rather than translating findings from adult research. ${ }^{9} 11$

A review of interventions for children suggests that educational or behavioural interventions may be potentially effective for promoting adherence, ${ }^{16}$ but this review excluded studies with negative findings, making it difficult to determine the overall utility of intervention. Educational and behavioural interventions are important as they are able to be implemented by individual health practitioners at various treatment stages. In the current review, we aimed to examine educational and behavioural interventions to promote adherence in young people receiving medication for a chronic illness.

\section{METHODS}

\section{Search strategy}

An extensive search for published literature was conducted. The following electronic databases 
were searched for the period January 1980 to June 2007: Medline (OVID), PsycINFO (OVID), CINAHL (OVID), International Pharmaceutical Abstracts (OVID), the Cochrane Library and Web of Science. Search strategy for OVID databases was: (adherence.ti OR compliance.ti OR concordance.ti) AND (child\$ OR adolesce\$ OR pediatr\$) AND (intervention OR treatment OR trial OR medication). Syntax was adjusted for specific databases. Reference lists were searched for potentially relevant articles.

\section{Inclusion criteria}

Criteria for inclusion in the review were: (1) participants aged 18 years and under and were receiving medication for at least 1 month; (2) study described a specific intervention aiming to improve medication adherence; (3) intervention did not involve changing the treatment provided and could be implemented by an individual health practitioner; (4) medication adherence outcomes were specifically reported; and (5) statistical comparisons were conducted for intervention and control group.

Studies were excluded from the review if: (1) participants were aged more than 18 years or insufficient detail was provided to ascertain participant age; (2) duration of pharmacological treatment was less than 1 month; (3) medication adherence outcomes were not reported; (4) the article did not examine a specific intervention; or (5) the study did not utilise a comparison group.

\section{Data extraction}

All identified abstracts were manually read for their applicability to inclusion and exclusion criteria. Resources were not available to translate articles written in languages other than English. Potentially relevant articles were then obtained and examined. Articles meeting inclusion criteria were scrutinised to extract the following information: sample characteristics (age range, clinical characteristics, sample size); experimental and control interventions; adherence outcomes and method used to measure adherence. Effect size was calculated for each study. Cohen's $d$ was calculated from means and SD. ${ }^{17}$ For manuscripts where only proportional data were available, strength of effect was quantified using OR and $95 \%$ CI, which were then converted to the equivalent of Cohen's d..$^{18}$

Study quality was assessed using the Delphi list. ${ }^{19}$ This instrument includes items relating to whether randomisation was conducted, whether treatment allocation was blinded, whether participant groups differed at baseline, and whether intention to treat analysis was conducted. Total scores are unweighted and range from 0 (poor quality) to 9 (high quality).

\section{RESULTS}

\section{Studies identified}

Database and reference searches yielded 2995 abstracts, which yielded 122 potentially relevant articles. Of these, 17 met inclusion criteria and were included in the final review (figure 1). Four articles written in languages other than English were identified via abstract as potentially relevant. One arti$\mathrm{cle}^{20}$ appeared to replicate a study already included in the current review. ${ }^{21}$ One study did not focus on young people, ${ }^{22}$ and two abstracts contained insufficient information to establish whether they reported on intervention studies..$^{23} 24$

Delphi scores ranged between 0 and 7 (mean 3.8). No studies blinded the patient or the care provider, and only four studies attempted to blind outcome assessment. All studies except for two utilised randomisation; one used a quasi-random technique allocating participant pairs to alternate treatments, ${ }^{25}$ whereas the other did not describe treatment allocation methods. ${ }^{26}$

Participant ages ranged from 9 months ${ }^{27}$ to 19 years. ${ }^{28-30}$ Three studies focused on younger children, ${ }^{21} 27{ }^{31}$ five studies recruited adolescents, ${ }^{29} 3032-34$ while nine recruited both children and adolescents. The majority of articles $(n=15)$ examined interventions in young people with no existing adherence problems. A variety of methods were used to measure medication adherence. Electronic monitoring (using MEMS, an electronic device measuring time and frequency of bottle opening), was used in two studies. Most studies utilised self or parent report of number of tablets taken, medication diaries or general adherence behaviour $(n=9)$. Four studies utilised serum or urine concentrations of drug or metabolite, and three studies utilised pharmacy dispensing records.

\section{Education alone}

Seven studies examined education interventions compared to treatment as usual. ${ }^{21} 253031$ 35-37 Education typically involved providing verbal or written information about the nature of the illness, rationale for treatment and benefits of adherence (table 1). Three studies examined a single education session, ${ }^{31} 3537$ whereas four studies examined repeated education sessions. ${ }^{21} 253036$

The largest study ${ }^{21}$ assessed three-monthly education using telephone contact, home visits or physician clinic visits, compared to treatment as usual. At follow-up, positive tests for urinary drug metabolite were reported in $85.0 \%$ of those

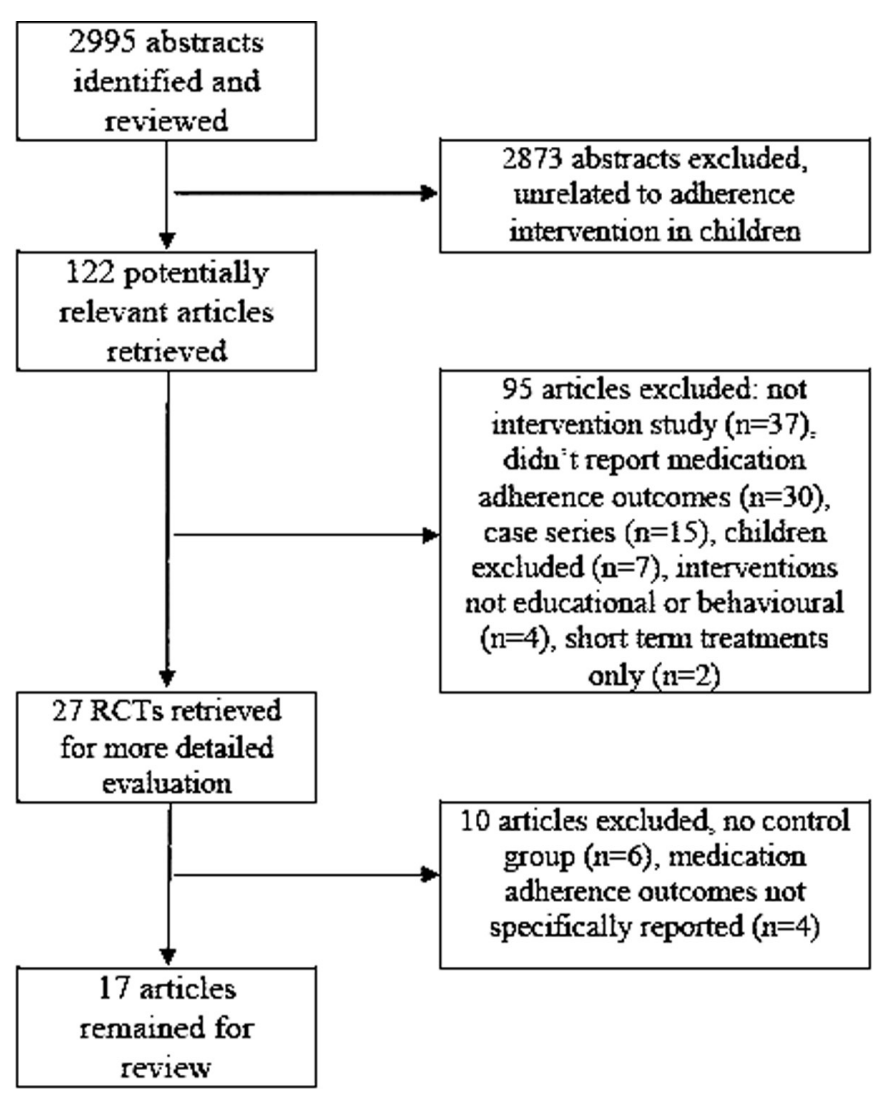

Figure 1 Flow chart of reviewed articles. 
Table 1 Trials utilising educational interventions

\begin{tabular}{|c|c|c|c|c|c|c|c|c|c|}
\hline Study & Age group & $\begin{array}{l}\text { Clinical } \\
\text { group }\end{array}$ & No & Intervention & Control & $\begin{array}{l}\text { Study } \\
\text { period }\end{array}$ & $\begin{array}{l}\text { Adherence } \\
\text { measure }\end{array}$ & $\begin{array}{l}\text { Key adherence } \\
\text { findings }\end{array}$ & $\begin{array}{l}\text { Delphi } \\
\text { score }\end{array}$ \\
\hline Salleras Sanmarti et a ${ }^{21}$ & $\begin{array}{l}\text { Children } \\
\text { (mean age } \\
6.5 \text { years) }\end{array}$ & $\begin{array}{l}\text { Tuberculosis } \\
\text { prophylaxis }\end{array}$ & 318 & $\begin{array}{l}\text { Group1: Education } \\
\text { (verbal) via } \\
3 \text { monthly telephone } \\
\text { call by specialist } \\
\text { nurses } \\
\text { Group 2: Education } \\
\text { (written and verbal), } \\
\text { via } 3 \text { monthly home } \\
\text { visits by specialist } \\
\text { nurses } \\
\text { Group } 3 \text { : Education } \\
\text { (written and verbal) } \\
\text { via } 3 \text { monthly clinic } \\
\text { visits with physician }\end{array}$ & Usual treatment & 12 months & $\begin{array}{l}\text { Urine testing } \\
\text { for drug } \\
\text { metabolite }\end{array}$ & $\begin{array}{l}\text { Groups } 1\left(\mathrm{~d}=0.82^{*}\right) \text {, } \\
2\left(\mathrm{~d}=1.08^{*}\right) \text {, and } 3 \\
\left(\mathrm{~d}=0.46^{*}\right) \text { superior to } \\
\text { control } \\
\text { Group } 2 \text { superior to } \\
\text { group } 3\left(\mathrm{~d}=0.62^{*}\right)\end{array}$ & 3 \\
\hline Hughes et $a l^{25}$ & $\begin{array}{l}\text { Children and } \\
\text { adolescents } \\
\text { (6-16 years) }\end{array}$ & Asthma & 95 & $\begin{array}{l}\text { Education: Specialist } \\
\text { care and home visits } \\
\text { (focusing on overall } \\
\text { asthma management } \\
\text { in addition to } \\
\text { adherence) }\end{array}$ & $\begin{array}{l}\text { Usual treatment } \\
\text { (primary care) }\end{array}$ & 12 months & $\begin{array}{l}\text { Medication } \\
\text { diary }\end{array}$ & $\begin{array}{l}\text { No significant group } \\
\text { differences for } \\
\text { adherence } \dagger \\
\text { Intervention led to } \\
\text { better asthma control } \\
\left(\mathrm{d}=0.66^{*}\right)\end{array}$ & 3 \\
\hline Holzheimer et $a l^{31}$ & $\begin{array}{l}\text { Children } \\
\text { (2-5 years) }\end{array}$ & Asthma & 80 & $\begin{array}{l}\text { Education: } \\
\text { Group 1. Asthma } \\
\text { education book and } \\
\text { video tape } \\
\text { Group 2. Asthma } \\
\text { video, control book } \\
\text { Group 3. Asthma } \\
\text { book, control video }\end{array}$ & $\begin{array}{l}\text { Control book and } \\
\text { control video }\end{array}$ & 3 months & $\begin{array}{l}\text { Medication } \\
\text { diary }\end{array}$ & $\begin{array}{l}\text { No significant group } \\
\text { differencest }\end{array}$ & 3 \\
\hline Jay et $a /^{30}$ & $\begin{array}{l}\text { Adolescent } \\
\text { girls } \\
\text { (14-19 years) }\end{array}$ & $\begin{array}{l}\text { Oral } \\
\text { contraceptive }\end{array}$ & 57 & $\begin{array}{l}\text { Education with } \\
\text { peer counsellor } \\
\text { (four sessions over } \\
4 \text { months) }\end{array}$ & $\begin{array}{l}\text { Education with } \\
\text { nurse }\end{array}$ & 4 months & $\begin{array}{l}\text { Broad health } \\
\text { behaviour } \\
\text { scale }\end{array}$ & $\begin{array}{l}\text { Intervention superior to } \\
\text { control at } 1(d=0.57) \\
\text { and } 2 \text { months }(d=0.24) \\
\text { No significant group } \\
\text { differences at } \\
4 \text { months }(d=0.20)\end{array}$ & 4 \\
\hline Farber et $a /^{37}$ & $\begin{array}{l}\text { Children and } \\
\text { adolescents } \\
\text { (2-18 years) }\end{array}$ & Asthma & 56 & $\begin{array}{l}\text { Education (single } \\
\text { session, videos and } \\
\text { discussion) }\end{array}$ & Usual treatment & 6 months & $\begin{array}{l}\text { Dispensing } \\
\text { frequency }\end{array}$ & $\begin{array}{l}\text { Adherence was } \\
\text { significantly higher in } \\
\text { the intervention group } \\
\text { compared to } \\
\text { control for preventer } \\
\text { medicationt but not } \\
\text { bronchodilatorst } \\
\text { Intervention group } \\
\text { had lower rates } \\
\text { of corticosteroid } \\
\text { undertreatment } \\
\text { (d=0.75*) }\end{array}$ & 6 \\
\hline Berrien et $a /^{36}$ & $\begin{array}{l}\text { Children and } \\
\text { adolescents } \\
\text { (1.5-20 years) }\end{array}$ & HIV & 37 & $\begin{array}{l}\text { Education-home } \\
\text { visits (intensive } \\
\text { individualised } \\
\text { nursing } \\
\text { intervention-8 } \\
\text { structured home } \\
\text { visits over 3-month } \\
\text { period focusing on } \\
\text { education and } \\
\text { resolving barriers to } \\
\text { adherence) }\end{array}$ & $\begin{array}{l}\text { Usual } \\
\text { treatment+single } \\
\text { home visit if } \\
\text { required }\end{array}$ & 3 months & $\begin{array}{l}\text { Self report } \\
\text { questionnaire } \\
\text { and } \\
\text { dispensing } \\
\text { frequency }\end{array}$ & $\begin{array}{l}\text { Intervention superior to } \\
\text { control for self-report } \\
\text { questionnaire } \\
\text { (d=0.66) and } \\
\text { dispensing frequency } \dagger\end{array}$ & 4 \\
\hline Baum et $a /^{35}$ & $\begin{array}{l}\text { Children and } \\
\text { adolescents } \\
\text { (6-16 years) }\end{array}$ & Asthma & 20 & $\begin{array}{l}\text { Education (single } \\
\text { session, } 2 \text { hours } \\
\text { involving written } \\
\text { information, video } \\
\text { and discussion } \\
\text { on disorder and } \\
\text { management) } \\
\text { and rewards for } \\
\text { completion of forms. }\end{array}$ & Usual treatment & 3 months & $\begin{array}{l}\text { Medication } \\
\text { diary and blood } \\
\text { testing for } \\
\text { theophylline }\end{array}$ & $\begin{array}{l}\text { No significant group } \\
\text { differencest }\end{array}$ & 1 \\
\hline
\end{tabular}

*Effect size equivalent calculated from $\mathrm{OR}$.

tData presented in the article do not permit calculation of effect sizes. 
receiving education via telephone (OR 4.4; CI 2.09 to 9.59), $89.8 \%$ of those receiving education via home visits (OR 7.02; CI 2.97 to 16.55$), 74.5 \%$ of those receiving education via clinic visits (OR 2.29; CI 1.18 to 4.49), compared to $55.8 \%$ in the control group $(p<0.025)$. Another study reported that provision of education within eight structured home nurse visits led to greater adherence based on dispensing frequency than clinic-based education, although group differences in adherence questionnaires were not statistically significant $(p=0.07$; Cohen's $d=0.66) .{ }^{36}$

Other studies were less clear. In young women receiving the contraceptive pill, adherence scores were better in those receiving education from a peer counsellor compared to a nurse counsellor at 1 and 2 months, but not at 4-month follow-ups. ${ }^{30}$ Another study in young people with asthma reported that compared to control, a single education session led to improved adherence for inhaled corticosteroids ( 2.0 vs 0.26 dispensing events over 6 months, $\mathrm{p}<0.001$ ), but not for bronchodilators (3.70 vs 2.56 dispensing episodes; $\mathrm{p}=0.34){ }^{37}$

The remaining three studies reported no significant effects on adherence. One study reported fewer non-compliance days in three intervention groups $(9.75,7.62$ and 9.08 days compared to 14.87 for control), but this was not significant. ${ }^{31} \mathrm{~A}$ small pilot study reported that a single session of education did not alter adherence at follow-up. ${ }^{35}$ Another study reported that home visits focusing on asthma management did not alter adherence, but did reduce asthma severity (OR 3.29; CI 1.07 to 10.13$){ }^{25}$

\section{Behavioural management}

Seven studies assessed behavioural management, with $(n=6)$ or without ( $\mathrm{n}=1$ ) education (table 2 ). Behavioural interventions included a range of techniques such as monitoring and goal setting, reinforcing medication taking with rewards, contingency contracting, problem solving and linking medication taking with established routines. Only one study examined behavioural management alone, comparing behavioural management with either self-esteem counselling or treatment as usual. Behavioural management led to significantly greater self-reported number of tablets taken $(179.93 \pm 57.01$ in the intervention group; $155.37 \pm 69.91$ and $150.98 \pm 73.75$ in counselling-control and treatment as usual groups). ${ }^{29}$

Six trials examined combined education and behavioural management. The largest of these ${ }^{38}$ reported that behavioural management and education led to a significantly greater percentage of asthma medication doses taken (78.0 $2.1 \%)$ compared to treatment as usual $(54.5 \pm 2.9 \%)$. In another asthma cohort, adherence behaviours rated on a 4 -point scale increased more in the intervention group (from $1.96 \pm 1.41$ to $3.14 \pm 1.16$ ) than control $(1.96 \pm 1.35$ to $2.14 \pm 1.37){ }^{28}$

Three smaller studies reported unclear findings. A study in children receiving sickle cell prophylaxis reported percentage of medication taken increased from $66.0 \%$ to $79.0 \%$ in those receiving the intervention, compared to the control group, which decreased from $69.3 \%$ to $66.0 \%(p=0.79) .{ }^{27}$ A study of children and adolescents receiving anticonvulsants converted serum drug concentrations to a 4-point adherence score (1=non-adherent, $4=$ =xcessive adherence). ${ }^{39}$ When findings were combined for all drugs, adherence scores in those completing the study were 2.9 in the intervention group compared to 2.2 in the control group $(F=6.36 ; p<0.05)$. This finding was not significant when drug groups were analysed separately or when all randomised participants were included in the analysis $(F=3.09 ; p=0.084) .{ }^{39}$ Another study in renal transplant recipients reporting that combined education and behavioural management led to better adherence for one medication (prednisone) but not others (azathioprine, ciclosporin). ${ }^{26}$

One study using MEMS, reported that proportion of doses taken was significantly higher in patients receiving both education and behavioural management $(77.7 \pm 21.5 \%)$, compared to those receiving education alone $(56.9 \pm 33.0 \%) .{ }^{40}$ However, no differences were detected in clinical outcomes, making difficult to determine the clinical importance of these findings.

\section{Combined education and psychological interventions}

Three studies utilised education in combination with another psychological intervention. In adolescents with depression, education and cognitive behavioural therapy was associated with poorer medication adherence $(203.4 \pm 145.8$ days of antidepressant medication) compared with treatment as usual (253.5 \pm 191.8 days of medication) $(\mathrm{F}=3.52 ; \mathrm{p}=0.06) .{ }^{33}$ Similarly, education and stress management training in adolescents with diabetes was associated with poorer medication adherence than control. ${ }^{32}$ Measuring adherence as the difference between time of insulin administration and time recommended via prescription, the first follow-up indicated poorer adherence in the intervention group (65.9 \pm 80.4 minutes) compared to control (24.8 \pm 40.7 minutes), and no group differences at later followups. ${ }^{32}$ In adolescents with asthma, the combination of education and group therapy led to superior adherence at 24 months, but not at 12 months. ${ }^{34}$

\section{DISCUSSION}

Only two of seven studies reported a clear benefit for education on medication adherence, whereas four of seven trials indicate beneficial effects of behavioural management. One trial reported that combining education with behavioural management may be more effective than education alone. Studies which combined education with other non-medication specific psychological interventions failed to demonstrate a beneficial effect on medication adherence.

Almost all reviewed studies utilised some form of education. Although education provision is an accepted part of clinical practice, ${ }^{15}$ many studies failed to demonstrate a clear benefit of education alone on adherence. Positive studies utilised multiple sessions, reinforcing the need to provide information regularly throughout treatment rather than just at treatment initiation. ${ }^{41}$ One study also reported a potential role for telephone-based education. The number of negative studies suggest that education, although important, may be insufficient to promote medication adherence. Interestingly, combining education with non-medication specific psychological interventions was not advantageous and in two studies was associated with poorer adherence. Adding psychotherapy to medication may provide an excuse for ceasing medications, exerting a 'treatment offset effect'. ${ }^{33}$ Young people receiving psychological therapy may not be protected from poor adherence, and may still require specific interventions to promote medication adherence.

A larger number of studies indicated that behavioural management may enhance adherence. There was no clear relation between intensity or duration of interventions and adherence outcome, making it difficult to recommend specific behavioural approaches. Nonetheless, findings indicate that adding 


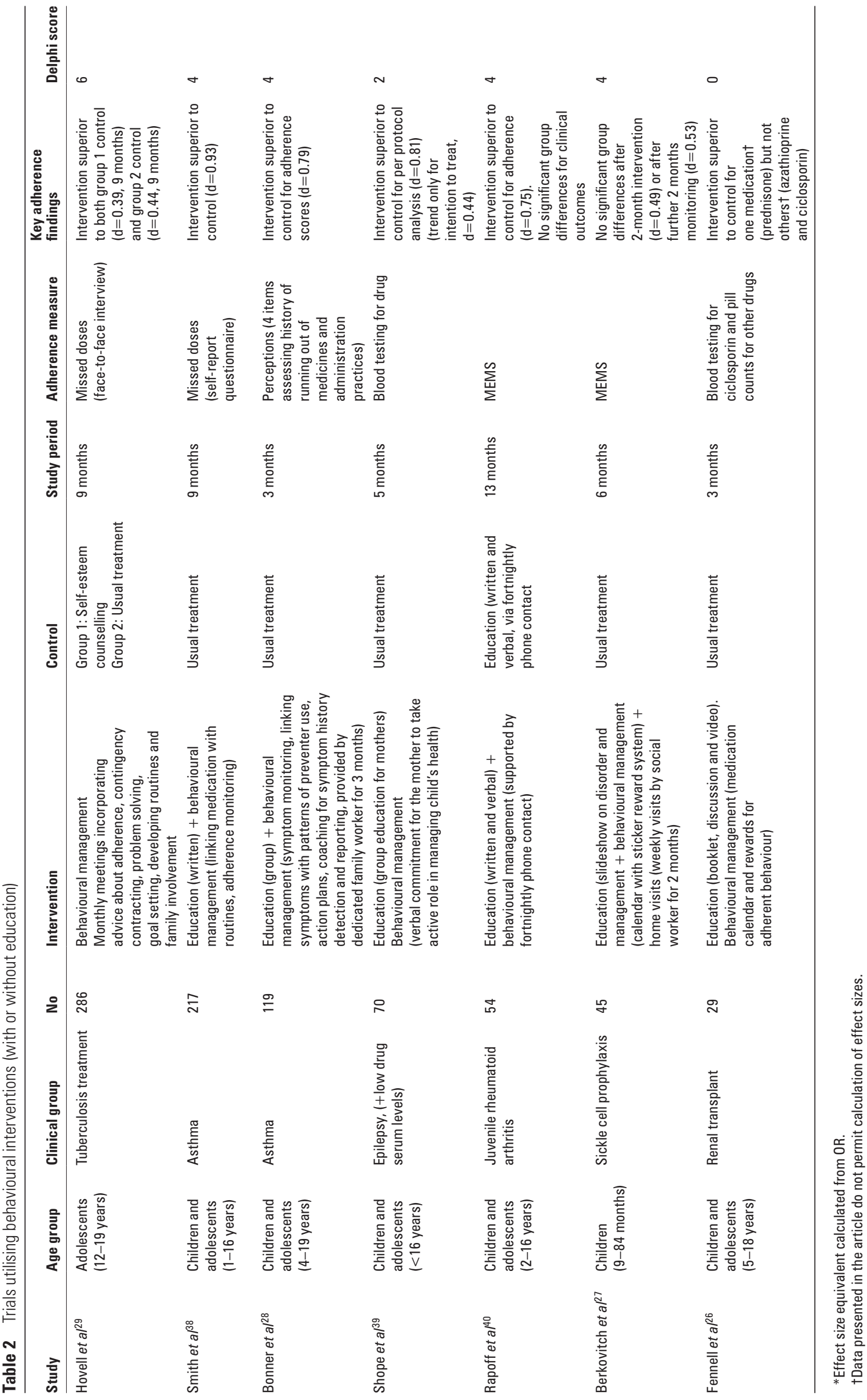


Table 3 Trials utilising educational interventions with other psychological intervention

\begin{tabular}{|c|c|c|c|c|c|c|c|c|c|}
\hline Study & Age group & $\begin{array}{l}\text { Clinical } \\
\text { group }\end{array}$ & No & Intervention & Control & Study period & $\begin{array}{l}\text { Adherence } \\
\text { measure }\end{array}$ & $\begin{array}{l}\text { Key adherence } \\
\text { findings }\end{array}$ & Delphi score \\
\hline Clarke et $a^{\beta 3}$ & $\begin{array}{l}\text { Adolescents } \\
\text { (12-18 years) }\end{array}$ & Depression & 152 & $\begin{array}{l}\text { Education } \\
\text { targeting SSRIs } \\
+ \text { brief cognitive } \\
\text { behavioural therapy } \\
\text { ( } 5-9 \text { sessions) for } \\
\text { depression }\end{array}$ & $\begin{array}{l}\text { Usual } \\
\text { treatment }\end{array}$ & 12 months & $\begin{array}{l}\text { Dispensing } \\
\text { frequency }\end{array}$ & $\begin{array}{l}\text { Intervention poorer } \\
\text { than control for } \\
\text { adherence } \\
\text { (d=-0.29) }\end{array}$ & 7 \\
\hline Van Es et $a^{34}$ & $\begin{array}{l}\text { Adolescents } \\
\text { (11-18 years) }\end{array}$ & Asthma & 112 & $\begin{array}{l}\text { Education } \\
\text { (8 sessions with } \\
\text { paediatrician/nurse) } \\
\text { + group therapy (3 } \\
\text { sessions exploring } \\
\text { attitudes, coping } \\
\text { skills, peers and } \\
\text { cigarette refusal) }\end{array}$ & $\begin{array}{l}\text { Usual } \\
\text { treatment }\end{array}$ & 24 months & $\begin{array}{l}\text { Self-report, } \\
\text { (Likert scale) }\end{array}$ & $\begin{array}{l}\text { Intervention superior } \\
\text { to control at } \\
24 \text { months }(d=0.46) \\
\text { but not } 12 \text { months } \\
(d=0.15)\end{array}$ & 5 \\
\hline Boardway et a/ ${ }^{32}$ & $\begin{array}{l}\text { Adolescents } \\
\text { (12-17 years) }\end{array}$ & $\begin{array}{l}\text { Diabetes } \\
\text { (+ history of poor } \\
\text { glycaemic control) }\end{array}$ & 32 & $\begin{array}{l}\text { Education }+ \text { stress } \\
\text { management } \\
\text { training (13 sessions } \\
\text { over } 6 \text { months, } \\
\text { incorporating } \\
\text { self-monitoring, } \\
\text { problem solving, } \\
\text { assertiveness, } \\
\text { coping and regimen } \\
\text { adherence issues) }\end{array}$ & $\begin{array}{l}\text { Usual } \\
\text { treatment }\end{array}$ & 9 months & $\begin{array}{l}\text { Time between } \\
\text { meal and insulin } \\
\text { dose, ( } 24 \text {-hour } \\
\text { recall interview) }\end{array}$ & $\begin{array}{l}\text { Intervention poorer } \\
\text { than control for } \\
\text { adherence at } \\
3 \text { months (trend, } \\
d=-0.64 \text { ) and no } \\
\text { group differences } \\
\text { at later follow-ups } \\
\text { ( } d=0.05 \text { and } 0.13 \text { ) }\end{array}$ & 4 \\
\hline
\end{tabular}

a behavioural component to education may optimise effects on medication adherence. First-line interventions could be selected based on their feasibility and applicability to developmental needs of the child. Interventions for young people with established poor adherence, lack of response to routine interventions or more complicated family issues may require more tailored interventions.

Most reviewed studies, including all studies demonstrating a beneficial treatment effect, utilised participants with no history of poor adherence. As such, these findings are not applicable to young people with established adherence problems. One challenge is that children who are at greatest risk for poor adherence, will also be most difficult to engage in research. ${ }^{42}$ Poor adherence is associated with a variety of risk factors, ${ }^{15}$ but data do not indicate how the reason for non-adherence might influence choice of adherence interventions. Ultimately, it remains appropriate to monitor adherence and clinical outcomes throughout treatment, using a stepped approach to interventions when responding to poor adherence. ${ }^{43}$ Most studies did not examine the role of age in assessing response to adherence interventions. Recommendations typically state that interventions should be targeted to the developmental needs of the child and family. However, little research has focused specifically on this issue, and whether the intervention should target the parent, the child or both.

This review raises a number of questions about improving care. Many primary care professionals could incorporate more regular information provision or simple behavioural techniques into existing practice. In primary care settings, medication information is typically provided by physicians and pharmacists. However, in contrast to adult adherence research, ${ }^{44}$ studies included for review rarely involved pharmacists, and typically relied on nurses, prescribers or researchers. Although the training and skills of health professionals may influence intervention outcomes, ${ }^{43} 45$ it is likely that many members of the multidisciplinary team can contribute to adherence interventions. Multidisciplinary approaches may also facilitate development of new interventions. ${ }^{46}$ One of the challenges for improving outcomes is the balance between standardised interventions typically used in research settings versus individualised approaches more typical of clinical practice. Further research in this area should consider the capacity for interventions to be implemented by diverse health professionals, and evaluate effectiveness in real-world settings.

This review has a number of limitations. Choice of search terms did not conform to all aspects of Cochrane search criteria. Although we selected terms to strike a balance between sensitivity and precision, it is possible that more sensitive searches would yield additional articles. The quality of studies included for review was typically poor, which is common in adherence research. ${ }^{43} 4446$ For example, most studies were not adequately blinded. This is logistically difficult in nondrug studies, but does compromise the strength of the positive findings. Many studies did not describe randomisation techniques or power calculations, and did not conduct intention to treat analysis. Many studies also relied on self-report of adherence. Although some adult studies suggest that selfreport has similar validity to electronic monitoring, ${ }^{47}$ studies in children suggest that parental self-report leads to overestimation of adherence. Selecting an appropriate control group is also difficult, as monitoring adherence is a core component of behavioural techniques, yet is also an essential component of measuring change in both intervention and control groups. It is possible that measurement of treatment effect may be limited by effect of adherence monitoring in the control group.

\section{CONCLUSIONS}

These findings indicate educational interventions alone are unlikely to enhance medication adherence in children and adolescents. Interventions which combined behavioural and educational approaches were more likely to demonstrate beneficial effects, but a number of negative studies reinforce the need for further research. In particular, few data are available to inform best practice for young people with existing adherence problems. Future research should examine those with poor adherence, the relation between efficacy and developmental stage and scope for implementation into practice settings. 
Acknowledgements AJD is supported by a fellowship provided by the National Health and Medical Research Council, Australia.

Funding Evidence-based Practice Unit, Queensland Health, Queensland Health Building, 147-163 Charlotte Street, Brisbane Queensland 4000, Australia.

\section{Competing interests None.}

Contributors All authors fulfil criteria for authorship, and no-one who fulfils criteria for authorship has been excluded.

Provenance and peer review Not commissioned; externally peer reviewed.

\section{REFERENCES}

1. World Health Organization. Adherence to Long-term Therapies: Evidence for Action. Geneva: World Health Organization, 2003.

2. Nevins TE. Non-compliance and its management in teenagers. Pediatr Transplant 2002;6:475-9.

3. Lehane E, McCarthy G. Medication non-adherence-exploring the conceptual mire. Int J Nurs Pract 2009:15:25-31.

4. van Dulmen S, Sluijs E, van Dijk L, et al. Patient adherence to medical treatment: a review of reviews. BMC Health Serv Res 2007;7:55.

5. DiMatteo MR, Giordani PJ, Lepper HS, et al. Patient adherence and medical treatment outcomes: a meta-analysis. Med Care 2002:40:794-811.

6. Charach A, Ickowicz A, Schachar R. Stimulant treatment over five years: adherence, effectiveness, and adverse effects. J Am Acad Child Adolesc Psychiatry 2004:43:559-67.

7. Sawyer SM, Aroni RA. Sticky issue of adherence. J Paediatr Child Health 2003;39:2-5.

8. Wise PH. The future pediatrician: the challenge of chronic illness. J Pediatr 2007:151:S6-10.

9. Butz AM. Evidence-based practice: what is the evidence for medication adherence in children? J Pediatr Health Care 2006:20:338-41.

10. Fiese BH, Everhart RS. Medical adherence and childhood chronic illness: family daily management skills and emotional climate as emerging contributors. Curr Opin Pediatr 2006;18:551-7.

11. KyngAs HA, Kroll T, Duffy ME. Compliance in adolescents with chronic diseases: a review. J Adolesc Health 2000:26:379-88.

12. Smith BA, Shuchman M. Problem of nonadherence in chronically ill adolescents: strategies for assessment and intervention. Curr Opin Pediatr 2005:17:613-18.

13. Dimatteo MR. The role of effective communication with children and their families in fostering adherence to pediatric regimens. Patient Educ Couns 2004;55:339-44.

14. Shaw RJ. Treatment adherence in adolescents: development and psychopathology. Clin Psychol Psychiat 2001:6:137-50.

15. Staples B, Bravender T. Drug compliance in adolescents: assessing and managing modifiable risk factors. Paediatr Drugs 2002;4:503-13.

16. Lemanek KL, Kamps J, Chung NB. Empirically supported treatments in pediatric psychology: regimen adherence. J Pediatr Psychol 2001;26:253-75.

17. Thalheimer W, Cook S. How to Calculate Effect Sizes from Published Research Articles: A Simplified Methodology, 2002. Retrieved 13 January 2010. http:// www.work-learning.com/effect sizes.htm.

18. Chinn S. A simple method for converting an odds ratio to effect size for use in meta-analysis. Stat Med 2000;19:3127-31.

19. Verhagen AP, de Vet HC, de Bie RA, et al. The Delphi list: a criteria list for quality assessment of randomized clinical trials for conducting systematic reviews developed by Delphi consensus. J Clin Epidemiol 1998;51:1235-41.

20. Alcaide Megías J, Altet Gómez MN, Canela Soler J, et al. [Influence of health education on compliance with antituberculous chemoprophylaxis in children: a community trial]. Rev Clin Esp 1990;187:89-93

21. Salleras Sanmarti L, Alcaide Megias J, Altet Gomez MN, et al. Evaluation of the efficacy of health education on the compliance with antituberculosis chemoprophylaxis in school children. A randomized clinical trial. Tuber Lung Dis 1993; 74:28-31.

22. Alvarez Gordillo Gdel C, Alvarez Gordillo JF, Dorantes Jiménez JE. [Educational strategy for improving patient compliance with the tuberculosis treatment regimen in Chiapas, Mexico]. Rev Panam Salud Publica 2003:14:402-8.

23. Urban C, Benesch M, Lackner $\mathrm{H}$, et al. The influence of maximum supportive care on dose compliance and survival. Single-center analysis of childhood acute
Jymphoblastic leukemia and non-Hodgkin's-lymphoma treated within 1984-1993. Klin Padiatr 1997;209:235-42

24. Joffroy-Rudzky C. [Expected benefits of a nursing consultation on the compliance of the adolescent renal transplantation patient]. Rech Soins Infirm 2006;84:105-17.

25. Hughes DM, McLeod M, Garner B, et al. Controlled trial of a home and ambulatory program for asthmatic children. Pediatrics 1991;87:54-61.

26. Fennell RS, Foulkes LM, Boggs SR. Family-based program to promote medication compliance in renal transplant children. Transplant Proc 1994;26:102-3.

27. Berkovitch M, Papadouris D, Shaw D, et al. Trying to improve compliance with prophylactic penicillin therapy in children with sickle cell disease. Br J Clin Pharmacol 1998:45:605-7.

28. Bonner S, Zimmerman BJ, Evans D, et al. An individualized intervention to improve asthma management among urban Latino and African-American families. $J$ Asthma 2002;39:167-79.

29. Hovell MF, Sipan CL, Blumberg EJ, et al. Increasing Latino adolescents' adherence to treatment for latent tuberculosis infection: a controlled trial. $A m J$ Public Health 2003;93:1871-7.

30. Jay MS, DuRant RH, Shoffitt T, et al. Effect of peer counselors on adolescent compliance in use of oral contraceptives. Pediatrics 1984;73:126-31.

31. Holzheimer L, Mohay H, Masters IB. Educating young children about asthma: comparing the effectiveness of a developmentally appropriate asthma education video tape and picture book. Child Care Health Dev 1998:24:85-99.

32. Boardway RH, Delamater AM, Tomakowsky J, et al. Stress management training for adolescents with diabetes. J Pediatr Psychol 1993:18:29-45.

33. Clarke G, Debar L, Lynch F, et al. A randomized effectiveness trial of brie cognitive-behavioral therapy for depressed adolescents receiving antidepressant medication. J Am Acad Child Adolesc Psychiatry 2005;44:888-98.

34. van Es SM, Nagelkerke AF, Colland VT, et al. An intervention programme using the ASE-model aimed at enhancing adherence in adolescents with asthma. Patient Educ Couns 2001:44:193-203

35. Baum D, Creer TL. Medication compliance in children with asthma. J Asthma 1986;23:49-59.

36. Berrien VM, Salazar JC, Reynolds E, et al.; HIV Medication Adherence Intervention Group. Adherence to antiretroviral therapy in HIV-infected pediatric patients improves with home-based intensive nursing intervention. AIDS Patient Care STDS 2004;18:355-63.

37. Farber HJ, Oliveria L. Trial of an asthma education program in an innercity pediatric emergency department. Pediatr Asthma Allergy Immunol 2004:17:107-15.

38. Smith NA, Seale JP, Ley P, et al. Effects of intervention on medication compliance in children with asthma. Med J Aust 1986;144:119-22

39. Shope JT. Intervention to improve compliance with pediatric anticonvulsant therapy. Patient Couns Health Educ 1980;2:135-41.

40. Rapoff MA, Belmont J, Lindsley C, et al. Prevention of nonadherence to nonsteroidal anti-inflammatory medications for newly diagnosed patients with juvenile rheumatoid arthritis. Health Psychol 2002;21:620-3.

41. Dean AJ, Witham M, McGuire T. Predictors of safety-related enquiries about psychotropic medication in young people and families accessing a medicines information service. J Child Adolesc Psychopharmacol 2009;19:179-85.

42. Riekert KA, Drotar D. Who participates in research on adherence to treatment in insulin-dependent diabetes mellitus? Implications and recommendations for research. J Pediatr Psychol 1999;24:253-8.

43. George J. Elliott RA, Stewart DC. A systematic review of interventions to improve medication taking in elderly patients prescribed multiple medications. Drugs Aging 2008:25:307-24.

44. Williams A, Manias E, Walker R. Interventions to improve medication adherence in people with multiple chronic conditions: a systematic review. J Adv Nurs 2008;63:132-43.

45. van Eijken $\mathbf{M}$, Tsang $\mathrm{S}$, Wensing $\mathbf{M}$, et al. Interventions to improve medication compliance in older patients living in the community: a systematic review of the literature. Drugs Aging 2003;20:229-40.

46. Haynes RB, Ackloo E, Sahota N, et al. Interventions for enhancing medication adherence. Cochrane Database Syst Rev 2008;2:CD000011.

47. Svarstad BL, Chewning BA, Sleath BL, et al. The Brief Medication Ouestionnaire: a tool for screening patient adherence and barriers to adherence. Patient Educ Couns 1999:37:113-24. 